\title{
PENGARUH BUDAYA ORGANISASI TERHADAP PERSONAL VALUE DAN PERILAKU IHSAN PEGAWAI UIN MAULANA MALIK IBRAHIM MALANG
}

\author{
Vivin Maharani Ekowati \\ Achmad Mu'is \\ Jurusan Manajemen Fakultas Ekonomi UIN Maulana Malik Ibrahim Malang \\ vivien.maharani@yahoo.com
}

\begin{abstract}
For Muslims, benevolent's behavior is highly recommended, because its a good behavior. To be able to compete to provide services for the patient, the nurse should be able to provide services based on the benevolent's behavior. The purpose of this study is to examine, test, and evaluate the influence of spiritual leadership, workplace spirituality, job satisfaction and benevolent's behavior. The study conducted in RSI Aisyiyah of Malang. Research population was all nurses. The Research samples were 60 nurses. Quistionare used to collect data from RSI Aisyiyah of Malang and the research data was analysis using PLS (Partial Least Square). The result showed that spiritual leadership significantly influenced workplace spirituality, spiritual leadership had no significantly influenced job satisfaction, spiritual leadership had no significantly influenced benevolent's behavior. Workplace spirituality significantly influenced job satisfaction, Workplace spirituality had no significantly influenced benevolent's behavior, job satisfaction significantly influenced benevolent's behavior. Based on the result, it can be concluded that job satisfaction is valuable organizational component. This component may become on organization's core competencies for improving benevolent's behavior, which are as sources of organizational competitive strengths in facing the rapidly changing business environments.
\end{abstract}

Keywords: Spiritual Leadership Workplace Spirituality, job satisfaction and benevolent's behavior.

Bagi umat islam, perilaku ihsan sangat dianjurkan oleh Nabi Muhammad SAW. Perilaku ihsan secara harfiah berbuat baik atau berbuat sebaik mungkin. Ismail (2011) mengungkapkan bahwa perilaku ihsan merupakan optimalisasi kerja dan berbuat, bekerja dan melaksanakan tugas sesuai dengan kinerja yang serba baik dan berkualitas tinggi. Pada perusahaan jasa perilaku ihsan dapat menjadi penentu keberhasilan atau kegagalan. Secara empiris banyak perilaku kerja pegawai belum secara keseluruhan menunjukkan perilaku ihsan yang islami walaupun organisasi tempatnya bekerja di bawah naungan organisasi islam. Islam tidak hanya mengajarkan kepada untuk beribadah semata, tetapi juga mengajarkan untuk beramal, dalam arti bekerja, bahkan meraih prestasi. Ini dibuktikan dari arti kata islam itu sendiri yang mengandung tiga makna: keselamatan, kedamaian, dan kesejahteraan. Untuk meraih kesejahteraan ini, Islam sangat mendorong umatnya untuk bekerja sebaik-baiknya dengan meraih prestasi (Buchari, 2009).

Perilaku ihsan dapat diartikan (1) melakukan sesuatu secara sempurna misalnya bekerja sesuai SOP, (2) membalas kebaikan dengan lebih baik, membalas kejelekan dengan sedikit, (3) mereduksi seoptimal mungkin akibat yang tidak menyenangkan, misalnya mencegah seseorang merasa kesakitan, (4) sebagai jalan keluar ketika keadilan optimal tidak bisa diwujudkan, (5) sebagai konsekuensi logis daripada iman, (6) sebagai investasi kesuksesan masa depan (Ibrahim, 2006).

Islam menekankan pemeluknya dalam bekerja hendaknya melakukan dengan penuh kecermatan, dengan penuh gairah dan rajin tidak bekerja seadanya. Kecermatan ini dalam islam dikenal dengan istilah ihsan. Ihsan akan menjamin terwujudnya kerja yang berkualitas (Buchari, 2009). Manusia diciptakan hanya untuk menghamba kepada Nya dalam bentuk apapun kegiatnnya. Karena itu dalam bekerja umat islam harus selalu memperoleh ridha Allah, dan harus melakukan amal saleh yang dikerjakan dengan ikhlas hanya karena Allah, sesuai dengan apa yang terdapat dalam QS Al-Kahfi:110, "Siapapun yang mengharapkan pertemuan dengan Nya hendaknya beramal saleh dan tidak menyekutukan dalam beribadat kepada Tuhannya dengan siapapun". 
Budaya organisasi telah disajikan sebagai sebuah fenomena yang menarik perhatian praktisi dan teoritikus di seluruh dunia setidaknya dalam dua decade terakhir (Ogbonna dan Haris, 1998). Budaya dapat diwujudkan dari nilai, ritual, pahlawan dan simbol, serta nilai ini tidak dapat diamati tetapi diwijudkan dalam alternative perilaku (Hofstede, et al. 1990). Perwujudan budaya ini dapat dikaitkan dengan level budaya dari Schein yang membedakan elemen-elemen dari budaya dengan memperlakukan asumsi dasar sebagai esensi. Artifak adalah level budaya yang paling nyata dan ciptaan, nilai adalah keinginan sadar, afektif atau kehendak, dan asumsi yang mendasari.

Personal value adalah modal terpenting dalam diri pegawai. Tanpa personal value, seseorang tidak akan mampu menjalankan perannya secara efektif. Dia tidak akan bisa menunaikan tanggung jawabnya secara baik. Beberapa mekanisme telah diajukan untuk membentuk personal value. Johnson (2004) menyatakan ada 4 proses yang membentuk personal value yaitu: (1) asumsi dasar, (2) perkembangan moral, (3) pengembangan kesadaran, (4) gabungan structural.

Handayanto (2014) menyatakan bahwa budaya organisasi tidak berpengaruh signifikan terhadap perilaku ihsan. Namun demikian, masih ada perbedaan hasil penelitian yang dilakukan untuk menguji hubungan budaya organisasi dengan perilaku ihsan seperti yang dilakukan Eskiler et al. (2016) yang menyatakan bahwa ada pengaruh antara budaya organisasi dengan perilaku benevolent. Demikian juga hasil penelitian dari Ellinger et al. (2012) menunjukan bahwa budaya organisasi berpengaruh terhadap perilaku kerja.
Studi mengenai pengaruh budaya organisasi terhadap perilaku ihsan mengungkap hasil yang tidak konsisten dengan adanya perbedaan temuan penelitian. Oleh sebab itu masih sangat diperlukan penelitian lebih lanjut untuk menguji pengaruh antara budaya organisasi terhadap personal value dan perilaku ihsan.

\section{BUDAYA ORGANISASI}

Schein dalam Ivancevich et al. (2005) mendefinisikan budaya sebagai suatu pola dari asumsi dasar yang diciptakan, ditemukan, atau dikembangkan oleh kelompok tertentu saat belajar menghadapi masalah adaptasi eksternal dan integrasi internal yang telah berjalan cukup baik untuk dianggap valid, dan oleh karena itu, untuk diajarkan kepada anggota baru sebagai cara yang benar untuk berpersepsi, berpikir dan berperasaan sehubungan dengan masalah yang dihadapinya.

Definisi Schein menunjukkan bahwa budaya melibatkan asumsi, adaptasi, persepsi dan pembelajaran. Lebih lanjut dijelaskan bahwa budaya organisasi memiliki tiga lapisan, lapisan pertama mencakup artifak dan ciptaan yang tampak nyata tetapi seringkali tidak dapat diinterpretasikan. Di lapisan kedua terdapat nilai atau berbagai hal yang penting bagi orang. Nilai merupakan kesadaran, hasrat afektif, atau keinginan. Pada lapisan ketiga merupakan asumsi dasar yang diciptakan orang untuk memandu perilaku mereka. Termasuk dalam lapisan ini adalah asumsi yang mengatakan kepada individu bagaimana berpersepsi, berpikir, dan berperasaan mengenai pekerjaan, tujuan kinerja, hubungan manusia, dan kinerja rekan kerja (Ivancevich et al., 2005).
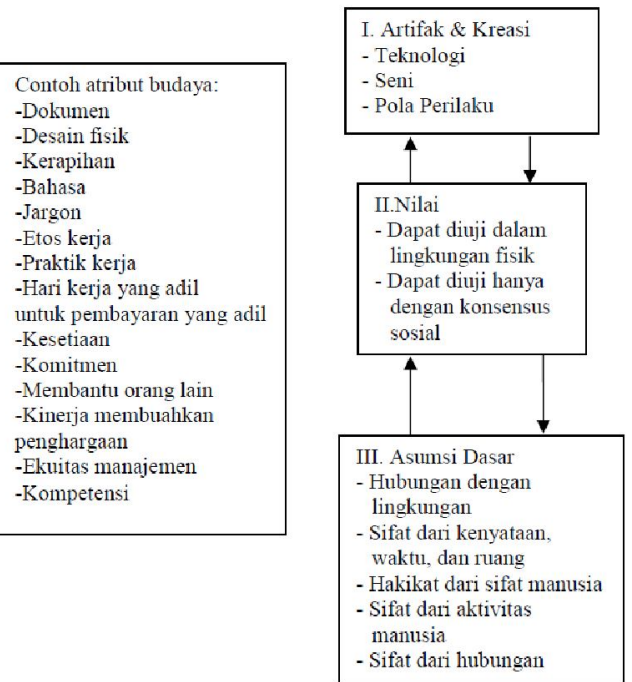

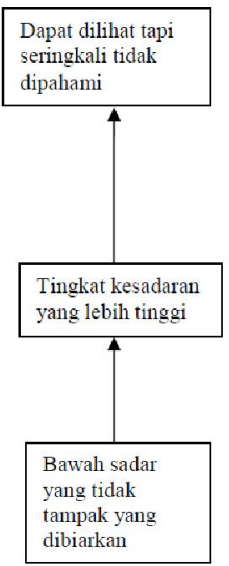

Gambar 2.1 Model Organisasi Tiga Lapis Schein 
Dalam etika atau budaya organsasi yang merupakan bagian ekonomi Islam, tidak lepas dari konsep konsep Islam (syari'ah) yang harus dilaksanakan dalam bidang tersebut. Arah penerapan konsep etika atau budaya organisasi Islam, yaitu merujuk pada" kewajiban-kewajiban sebuah organisasi untuk melindungi dan memberi konstribusi kepada masyarakat dimana ia berada (Rafik Issa Bekum, 2004). Sebuah organisasi mengemban tanggung jawab sosial dalam tiga domain: (1) pada pelaku organisasi, (2) pada lingkungan alam, dan (3) pada kesejahteraan sosial secara umum.

Harus disadari bahwa sebuah organisasi yang baik harus disertai dengan nilai-nilai yang diyakini oleh setiap elemen organisasi. Tentu nilai-nilainya adalah islam. Dalam firman Allah dijelaskan tentang bagaimana manusia hidup secara bersama atau kelompok.

Hai manusia, sesuangguhnya kami menciptakan kamu dari seseorang laki-laki dan perempuan, dan menjadikan kamu berbangsa-bangsa dan bersukusuku supaya kamu saling kenal mengenal. Sesungguhnya orang yang paling mulai diantara kamu di sisi Allah adalah orang yang paling takwa diantara kamu. Sesungguhnya Allah maha mengetahui lagi maha mengenal. QS Al Hujurat : 13.

Ayat ini mempunyai makna bahwa manusia diciptakan Allah dari laki-laki dan perempuan, dan akhirnya mereka mempunyai budaya dunia yang berkaitan dengan tata cara hidup masing-masing dari mereka. Namun Allah memperingatkan kepada manusia, bahwa manusia harus menjauhi larangan Nya dan menjalankan perintah-Nya. Dalam mencapai derajat takwa, tentu tidak terlepas dari interaksi dengan orang lain dan alam sekitarnya. Kegiatan timbal balik antara manusia dan lingkungan merupakan peristiwa sosial penting yang berujung pada pengayaan budaya. Interaksi itu tidak hanya terbentuk begitu saja, akan tetapi ada item yang memfasilitasi hal tersebut, sehingga individu bisa saling mengenal dan individu mempunyai gambaran kehidupan dengan tujuan yang sama dan direalisasikan menjadi awal organisasi sebagai fasilitas dakwah.

\section{Personal value}

Personal value dalam Islam dapat dilihat dari personal value orang per orang dan dalam kelompok. Personal value individu meliputi ciri khas seseorang dalam sikap dan tingkah laku, serta kemampuan intelektual. Karena ada unsur personal value masingmasing, maka setiap individu akan menampilkan personal value yang berbeda. Secara fitrah perbedaan ini memang ada. Islam memandang setiap manusia memiliki potensi yang berbeda, sehingga kepada setiap orang dituntut untuk menunaikan perintah agamanya sesuai dengan tingkat kemampuan masingmasing.

Walaupun setiap individu mempunyai personal value yang berbeda, tapi dalam pembentukan personal value muslim sebagai umat, perbedaan itu perlu dipadukan. Sumber yang menjadi dasar dan tujuannya adalah ajaran wahyu. Dasar pembentukan adalah $\mathrm{Al}$ Quran dan hadist, sedangkan tujuan yang akan dicapai adalah menjadi pengabdi Allah yang setia (QS 51:56) sebagai Tuhan yang wajib disembah. Sedangkan pengabdian yang dimaksud didasarkan atas tuntutan untuk menyembah kepada Tuhan yang satu sebagai dalamAl Qur'an: artinya: “Itulah dia Allah Tuhan kamu, tidak ada yang berhak disembah selain dia. Pencipta segala sesuatu, maka sembahlah dia (QS. 6:102).

Al Qur'an mengkaitkan perilaku ihsan ke dalam dua sasaran utama, yaitu memperlihatkan ibadah yang terbaik secara tulus. Yang kedua menyembah Allah dengan penuh kesungguhan (Ismail, 2011). Jadi ihsan mengajarkan kita tiga hal, yaitu kita harus melakukan sesuatu sebaik mungkin (optimal), kita harus mengimprovisasi pengetahuan dan kemampuan yang berkaitan dengan tugas sehingga dapat bekerja secara optimal, kita harus bisa menjauhkan diri dari sikap bekerja asal-asalan karena yang demikian tidak sesuai dengan ajaran islam.

\section{Model Hipotesis}

Berdasarkan kerangka pemikiran di atas, maka dibuat model konsepsi sebagai berikut:

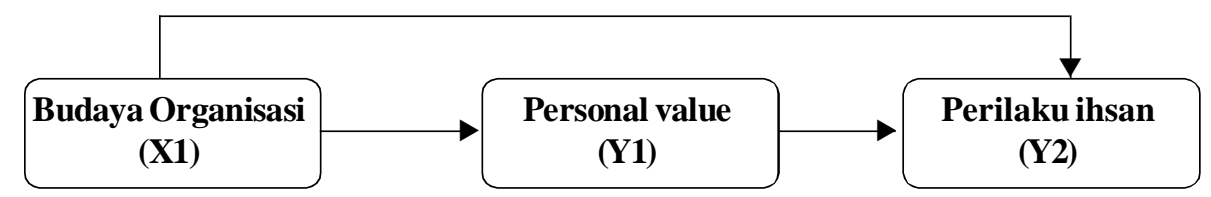

Keterangan : $\longrightarrow$ Pengaruh

Gambar 1 Model Hipotesis yang Menjelaskan Pengaruh antara Budaya organisasi, Peronal value dan Perilaku Ihsan 


\section{METODE PENELITIAN}

Penelitian ini menggunakan pendekatan explanatory research. Penelitian explanatory research dimaksudkan untuk memberikan penjelasan hubungan kausal antar variabel melalui pengujian hipotesis atau bertujuan untuk memperoleh pengujian yang tepat dalam menarik kesimpulan yang bersifat kausalitas (sebab akibat) antara dua variabel atau lebih melalui pengujian hipotesis (Sekaran, 2003).

\section{Populasi, Sampel dan teknik pengambilan sampel}

Populasi dalam penelitian ini adalah seluruh pegawai di Uin Maulana Malik Ibrahim Malang. Populasi seluruh pegawai dengan jumlah total 350 pegawai. Dengan ukuran populasi sebanyak 350 orang, dan presisi $10 \%$, maka ukuran sampel adalah 78 pegawai.

Teknik pengambilan sampel yang digunakan dalam penelitian ini adalah teknik proportional random sampling, yaitu teknik pengambilan sampel dimana semua anggota populasi mempunyai kesempatan untuk dijadikan sampel sesuai dengan proporsi per bagian (Sekaran, 2003). Alasan penggunaan teknik proporsional random sampling karena pegawai ditempatkan di berbagai fakultas dan di kantor pusat, dimana masing-masing fakultas dan kantor pusat merupakan bagian yang tidak dapat dipisahkan.

\section{Metode Analisis Data}

\section{Analisis Statistik deskriptif}

Analisis deskripsi bertujuan untuk mengintepretasikan mengenai argumen responden terhadap pilihan pernyataan dan distribusi frekuensi pernyataan responden dari data yang telah dikumpulkan.

\section{Path Analysis}

Untuk menjawab permasalahan berikutnya dise- suaikan dengan model hipotesis, di mana untuk menguji hipotesis penelitian ini digunakan teknik Analisis Jalur (Path Analysis). Untuk hipotesis ini digunakan analisis jalur, sehingga dapat dilakukan estimasi besarnya hubungan kausal antar sejumlah variabel dan hirarkhi kedudukan masing-masing variabel dalam serangkaian jalur-jalur hubungan kausal, baik langsung maupun tidak langsung (Solimun, 2012).

\section{Analisis Variabel Mediasi}

Analisis variabel mediasi dapat dilakukan melalui dua pendekatan yaitu perbedaan koefisien dan perkalian koefisien. Pendekatan perbedaan koefisien menggunakan metode pemeriksaan dengan melakukan analisis dengan dan tanpa melibatkan variabel mediasi. Sedangkan metode perkalian dilakukan dengan metode Sobel.

\section{HASIL DAN PEMBAHASAN}

\section{Analisis Jalur Budaya Organisasi (X) terhadap Personal Value (Y1).}

Pada Tabel 1 dapat diketahui bahwa nilai t hitung adalah sebesar 5.012 dengan angka probabilitas sebesar $0.000(p<0.05)$, maka $\mathrm{H}_{0}$ Ditolak. Hal ini berarti berdasarkan hasil penelitian menunjukkan bahwa budaya organisasi mempunyai pengaruh yang signifikan terhadap personal value, dengan demikian hipotesis yang menyatakan budaya organisasi mampu meningkatkan personal value dapat diterima.

Nilai multiple R sebesar 0,494 ini mengandung makna bahwa terdapat hubungan yang sedang antara variabel budaya organisasi terhadap personal value. Variasi perubahan nilai variabel personal value (Y1) yang dapat dijelaskan oleh budaya organisasi (X) yang ditunjukkan oleh angka koefisien determinasi atau $\mathrm{R}^{2}$ disesuaikan yaitu sebesar $24.4 \%$ dan selebihnya

Tabel 1 Ringkasan Hasil analisis Jalur Budaya Organisasi (X) terhadap Personal Value (Y1)

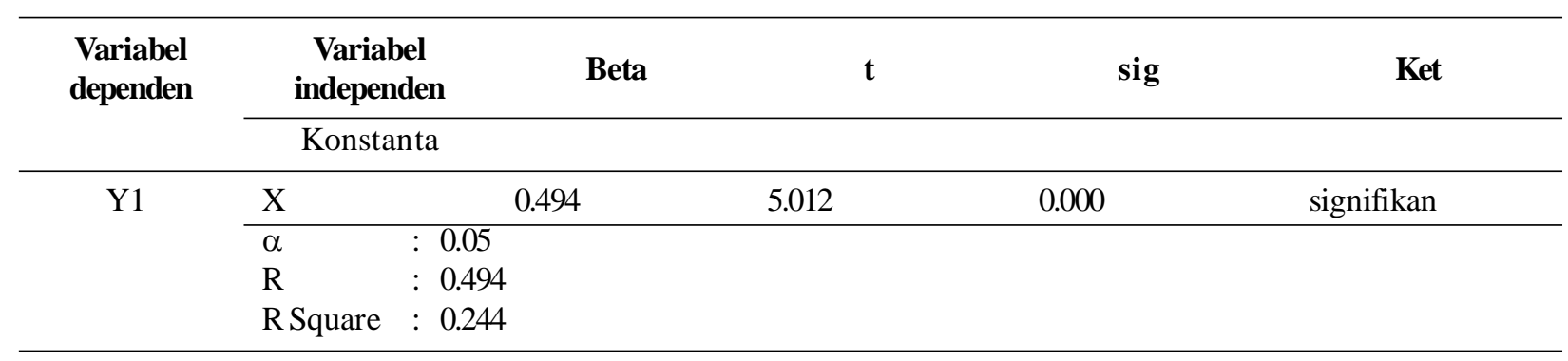

Sumber : Lampiran 
dipengaruhi oleh variabel lain.

Analisis Jalur Budaya Organisasi (X), Personal Value (Y1) terhadap Perilaku Ihsan (Y2)

Tabel 2 Ringkasan Hasil analisis jalur Regresi Budaya Organisasi (X), Personal Value (Y1) terhadap Perilaku Ihsan (Y2)

\begin{tabular}{|c|c|c|c|c|c|}
\hline & Variabe & Beta & $\mathbf{t}$ & sig & Ket \\
\hline \multirow[t]{2}{*}{ Y2 } & $X$ & 1.133 & 52.302 & 0.000 & signifikan \\
\hline & $\mathrm{Y} 1$ & 0.519 & 23.958 & 0.000 & signifikan \\
\hline \multirow{5}{*}{$\begin{array}{l}\text { Regresi } \\
\text { Model } 2\end{array}$} & $\alpha$ & $: 0.05$ & & & \\
\hline & $\mathrm{R}$ & : 0.986 & & & \\
\hline & R Square & : 0.973 & & & \\
\hline & F Hitung & $: 1.370 .000$ & & & \\
\hline & Sig. F & $: 0.000$ & & & \\
\hline
\end{tabular}

Sumber : Lampiran

Pada Tabel 2 dapat diketahui bahwa nilai $F$ hitung adalah sebesar 1.370.000 dengan angka probabilitas sebesar $0.000(\mathrm{p}<0.05)$, maka $\mathrm{H}_{0}$ Ditolak. Hal ini berarti berdasarkan hasil penelitian menunjukkan bahwa budaya organisasi dan personal value secara bersama-sama mempunyai pengaruh yang signifikan terhadap perilaku ihsan. Nilai multiple R sebesar 0,986 ini mengandung makna bahwa terdapat hubungan yang sangat erat antara variabel budaya organisasi dan personal value terhadap perilaku ihsan. Variasi perubahan nilai variabel perilaku ihsan (Y2) yang dapat dijelaskan oleh budaya organisasi dan personal value yang ditunjukkan oleh angka koefisien determinasi atau $\mathrm{R}^{2}$ disesuaikan yaitu sebesar $97.3 \%$ dan selebihnya dipengaruhi oleh variabel lain.

Pada Tabel diatas menunjukkan nilai p $(0.000)<$ $(0,05)$. Ini berarti ada pengaruh yang signifikan antara budaya organisasi (X) terhadap Perilaku Ihsan (Y2) pada taraf signifikansi 95\%. Berdasarkan uji analisis, dapat diketahui bahwa untuk variabel budaya organisasi (X), diperoleh nilai t sebesar 52.302, dengan taraf signifikansi $0.000<0,05$. Hal ini menunjukkan bahwa terdapat pengaruh yang signifikan antara budaya organisasi (X) terhadap Variabel Perilaku Ihsan (Y2).

Pada Tabel di atas menunjukkan nilai p (0.000) $<(0,05)$. Ini berarti ada pengaruh yang signifikan antara personal value $\left(\mathrm{Y}_{1}\right)$ terhadap Variabel Perilaku Ihsan (Y2) pada taraf signifikansi 95\%. Berdasarkan uji analisis, dapat diketahui bahwa untuk variabel personal value $\left(\mathrm{Y}_{1}\right)$, diperoleh nilai $\mathrm{t}$ sebesar 23.958; dengan taraf signifikansi $0.000<0.05$. Hal ini menunjukkan bahwa ada pengaruh yang signifikan antara personal value $\left(\mathrm{Y}_{1}\right)$ terhadap Variabel Perilaku Ihsan (Y2).

\section{Analisis Hipotesis Masing-masing jalur}

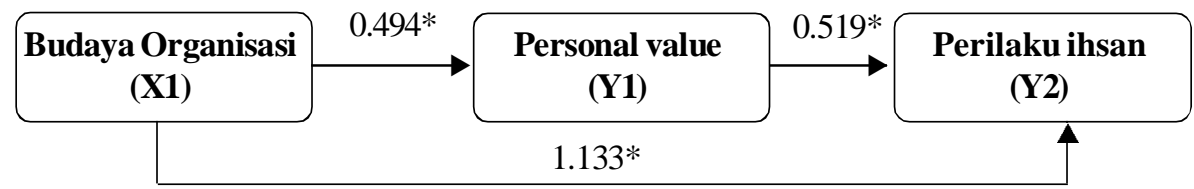

Gambar 2 Hasil Analisis Jalur

Karena koefisien jalur bertanda positif (1.133) mengindikasikan pengaruh keduanya searah. Artinya, semakin baik budaya organisasi, maka akan mengakibatkan semakin baik juga perilaku ihsan.
Hasil analisis jalur pengaruh tidak langsung variabel budaya organisasi terhadap perilaku ihsan diperoleh nilai 0.256 yang merupakan hasil perkalian dari 0.494 x 0.519. Nilai 0.494 merupakan jalur antara budaya 
organisasi terhadap personal value; nilai 0.519 merupakan jalur antara personal value dengan perilaku ihsan.

Dilihat dari besarnya koefisien jalur, baik jalur langsung maupun tidak langsung semuanya menunjukkan signifikan. Besarnya koefisien jalur langsung antara budaya organisasi terhadap perilaku ihsan sebesar 1.133. Sedangkan besarnya koefisien jalur pengaruh tidak langsung antara budaya organisasi ke perilaku ihsan melalui personal value sebesar 0.256 .

Dari uraian di atas, dapat disimpulkan bahwa besarnya koefisien jalur langsung lebih besar daripada koefisien jalur tidak langsung.

\section{Uji Mediasi}

Tabel 3 Ringkasan Hasil analisis Jalur Mediasi Model 1, 2 dan Model 3

\begin{tabular}{|c|c|c|c|c|c|c|}
\hline \multirow{4}{*}{$\begin{array}{l}\text { Y1 } \\
\text { Jalur } \\
\text { Model } 1\end{array}$} & \multicolumn{2}{|l|}{ Variabel } & Beta & $\mathbf{t}$ & sig & Ket \\
\hline & \multicolumn{6}{|l|}{ Konstanta } \\
\hline & $X$ & & 0.494 & 5.012 & 0.000 & signifikan \\
\hline & $\begin{array}{l}\alpha \\
\text { R } \\
\text { R Square } \\
\text { t Hitung } \\
\text { Sig.t }\end{array}$ & $\begin{array}{ll}: & 0.05 \\
: & 0.494 \\
: & 0.244 \\
: & 5.012 \\
: & 0.000\end{array}$ & & & & \\
\hline & Variabel & & Beta & $\mathbf{t}$ & sig & Ket \\
\hline $\mathrm{Y} 2$ & $X$ & & 1.133 & 52.302 & 0.000 & signifikan \\
\hline & $\mathrm{Y} 1$ & & 0.519 & 23.958 & 0.000 & signifikan \\
\hline Model 2 & $\begin{array}{l}\alpha \\
\mathrm{R} \\
\text { R Square } \\
\text { F Hitung } \\
\text { Sig. F }\end{array}$ & $\begin{array}{ll}: & 0.05 \\
: & 0.986 \\
: & 0.973 \\
: & 1.370 .000 \\
: & 0.000\end{array}$ & & & & \\
\hline & Variabel & & Beta & $\mathbf{t}$ & sig & Ket \\
\hline $\mathrm{Y} 2$ & $X$ & & 0.877 & 16.110 & 0.000 & signifikan \\
\hline Model 3 & $\begin{array}{l}\alpha \\
\mathrm{R} \\
\text { R Square } \\
\text { t Hitung } \\
\text { Sig.t }\end{array}$ & $\begin{array}{ll}: & 0.05 \\
: & 0.877 \\
: & 0.769 \\
: & 16.110 \\
: & 0.000\end{array}$ & & & & \\
\hline
\end{tabular}

Sumber: Lampiran

Hasil analisis jalur pengaruh langsung variabel budaya organisasi terhadap perilaku ihsan diperoleh nilai 1.133 . Nilai $p$ value sebesar 0.000 . Karena pvalue $<5 \%$, maka budaya organisasi berpengaruh langsung terhadap perilaku ihsan. Dengan demikian dapat diartikan bahwa budaya organisasi berpengaruh terhadap perilaku ihsan.
Hasil analisis jalur pengaruh langsung variabel personal value terhadap perilaku ihsan diperoleh nilai 0.519 dengan nilai sig sebesar $0.000<5 \%$, maka personal value berpengaruh langsung terhadap perilaku ihsan.

Hasil analisis jalur pengaruh langsung variabel budaya organisasi terhadap personal value diperoleh 
nilai 0.494 . Nilai $\mathrm{p}$ value sebesar 0.000 . Karena $\mathrm{p}$ value $<5 \%$, maka budaya organisasi berpengaruh langsung terhadap personal value. Dengan demikian dapat diartikan bahwa budaya organisasi berpengaruh terhadap personal value.

Hasil analisis jalur pengaruh tidak langsung variabel budaya organisasi terhadap perilaku ihsan diperoleh nilai 0.256 yang merupakan hasil perkalian dari $0.494 \times 0.519$. Nilai 0.494 merupakan jalur antara budaya organisasi terhadap personal value; nilai 0.519 merupakan jalur antara personal value dengan perilaku ihsan. Nilai p value sebesar 0.000 . Karena p-value $<5 \%$, maka budaya organisasi berpengaruh tidak langsung terhadap perilaku ihsan.

Bukti nyata empiris ini memberikan respon yang positif terhadap hasil penelitian dari $\mathrm{Wu}, \mathrm{Hu}$ and Jiang (2012) bahwa budaya organisasi berpengaruh terhadap personal value. Hasil penelitian juga mendukung penelitian dari Handayanto et al (2014) yang menunjukkan bahwa budaya organisasi berpengaruh terhadap personal value. Hasil penelitian di lapangan mendukung pendapat Robbins (2003) bahwa budaya organisasi merupakan sistem makna bersama yang dianut oleh anggota-anggota yang membedakan suatu organisasi dari organisasi lain.

Berbeda dengan di beberapa tempat lain, UIN Maliki Malang berusaha memformat diri menjadi lembaga pendidikan tinggi Islam ideal. Pikiran-pikiran yang pijakan selama ini adalah bahwa perguruan tinggi Islam seharusnya mampu mengantarkan mahasiswa memiliki empat kekuatan, yaitu: (1) kedalaman spiritual, (2) keagungan akhlaq, (3) keluasan ilmu dan (4) kematangan profesional. Untuk membangun semua kekuatan itu, UIN Maliki Malang berusaha menggabungkan tradisi pesantren dan tradisi perguruan tinggi, dan itulah nantinya yang diharapkan lahir sosok perguruan tinggi Islam yang ideal itu. Selama ini perguruan tinggi lebih menekankan aspek akademik, sedangkan pesantren lebih mengedepankan akhlak dan spiritual lewat kultur yang dikembangkan. Jika kedua kekuatan ini (tradisi kampus dan pesantren) dipadukan maka diharapkan lahir budaya Islami yang mendekati ideal sebagaimana yang ditunggu-tunggu kehadirannya oleh umat Islam di Indonesia.

Perubahan budaya UIN Maliki Malang tidak menggunakan pendekatan agresif. Hal ini dikarenakan budaya organisasi lama di UIN Maliki Malang sangat kuat melekat sehingga memerlukan proses yang tidak drastis. Dengan berubahnya STAIN Malang menjadi IAIN lalu UIIS terakhir menjadi UIN Maliki Malang tentu membawa sejumlah implikasi terhadap berbagai bentuk perubahan dan pengembangan di lembaga perguruan tinggi Islam ini. Pengembangan yang memang diharapkan seiring dengan perubahan status lembaga pendidikan Islam ini adalah terkait dengan nilai-nilai dan budaya bernafaskan keislaman.

Visi dan misi UIN Maliki Malang tidak lepas dari buah pikiran cemerlang Prof. Imam Suprayogo yang menjabat Rektor selama empat periode yang berakhir pada Mei 2013. Gagasan, ide dan pandangan beliau kemudian dituangkan dalam bentuk visi dan misi organisasi. Dominasi visi misi organisasi UIN Maliki Malang terletak pada sang Rektor saat itu demikian pula dalam implementasi dari visi dan misi organisasi yang mengandalkan kekuatan pemimpin.

Berdasarkan hasil path analisis, menunjukkan bahwa budaya organisasi berpengaruh secara langsung terhadap perilaku ihsan, dengan nilai beta 1.133. Karena koefisien jalur bertanda positif (1.133) mengindikasikan pengaruh keduanya searah. Artinya, jika semakin baik budaya organisasi, maka semakin meningkat pula perilaku ihsan.

Temuan ini memperkuat hasil penelitian terdahulu diantaranya penelitian dari Eskiler et al. (2016) bahwa ada korelasi positif antara budaya organisasi dengan perilaku inovatif. Demikian juga dapat dibuktikan adanya pengaruh antara budaya organisasi dengan perilaku inovatif. Demikian juga dengan penelitian dari Ellinger et al. (2012) bahwa budaya organisasi berpengaruh terhadap perilaku kerja (benevolent) para pegawai.

Budaya organisasi melibatkan ekspektasi, nilai, dan sikap bersama, hal tersebut memberikan pengaruh pada individu, kelompok, dan proses organisasi (Ivancevich et.al., 2006: 46). Hasil penelitian menunjukkan bahwa dampak dari budaya terhadap karyawan menunjukkan bahwa budaya menyediakan dan mendorong suatu bentuk stabilitas. Terdapat perasaan stabilitas, selain perasaan identitas organisasi yang disediakan oleh budaya organisasi. Organisasi yang memiliki budaya yang kuat dicirikan oleh adanya karyawan yang memiliki nilai inti bersama. Semakin banyak karyawan yang berbagi dan menerima nilai inti, semakin kuat budaya, dan semakin besar pengaruhnya terhadap perilaku ihsan.

Perilaku ihsan didasarkan pada ayat Al Quran (28:77) yaitu berbuat baiklah kamu (kepada orang lain) seperti Allah telah berbuat baik kepadamu. Perilaku ihsan tercermin dari beberapa indikator yaitu melakukan sesuatu dengan sempurna (perfect); membalas kebaikan dengan lebih; mereduksi akibat tidak menye- 
nangkan; konsekuensi logis daripada iman; dan investasi kesuksesan masa depan.

$\mathrm{Al}$ Qur'an mengkaitkan perilaku ihsan ke dalam dua sasaran utama, yaitu memperlihatkan ibadah yang terbaik secara tulus. Yang kedua menyembah Allah dengan penuh kesungguhan (Ismail, 2011). Jadi ihsan mengajarkan kita tiga hal, yaitu kita harus melakukan sesuatu sebaik mungkin (optimal), kita harus mengimprovisasi pengetahuan dan kemampuan yang berkaitan dengan tugas sehingga dapat bekerja secara optimal, kita harus bisa menjauhkan diri dari sikap bekerja asal-asalan karena yang demikian tidak sesuai dengan ajaran islam.

Berdasarkan hasil analisis jalur pengaruh tidak langsung variabel budaya organisasi terhadap perilaku ihsan diperoleh nilai 0.256 yang merupakan hasil perkalian dari $0.494 \times 0.519$. Nilai 0.494 merupakan jalur antara budaya organisasi terhadap personal value; nilai 0.519 merupakan jalur antara personal value dengan perilaku ihsan. Dilihat dari besarnya koefisien jalur, baik jalur langsung maupun tidak langsung semuanya menunjukkan signifikan. Besarnya koefisien jalur langsung antara budaya organisasi terhadap perilaku ihsan sebesar 1.133. Sedangkan besarnya koefisien jalur pengaruh tidak langsung antara budaya organisasi ke perilaku ihsan melalui personal value sebesar 0.256 .

Hasil penelitian mendukung penelitian terdahulu yang dilakukan oleh Handayanto et al (2014) bahwa budaya organisasi berpengaruh terhadap personal value. Lages dan Vernandes (2005) menyatakan bahwa personal value terdiri dari service value peaceful live, service value to social recognition, service value to social integration. Ketiga hal tersebut dijelaskan ke beberapa kriteria pegawai yaitu dengan menjadi pegawai di UIN atau dengan bekerja di UIN memberikan lebih banyak ketenangan, pegawai lebih banyak memdapatkan keselarasan dalam kehidupan, pegawai mendapatkan kehidupan lebih menyenangkan, bekerja di UIN membuat pegawai mendapat penghargaan dari orang lain, dengan bekerja di UIN kehidupan pegawai sesuai dengan nilai-nilai atau keinginan yang selama ini diharapkan, UIN juga memberikan pengakuan sosial.

Temuan di lapangan menggambarkan bahwa asumsi dan kepercayaan adalah awal bagi personal value yang kemudian membantu membentuk sikap. Tentang perilaku terencana dimana sikap, norma subyektif, keinginan dan persepsi kontrol dibangun sebagai faktor yang mempengaruhi perilaku. Manifestasi perilaku ihsan dapat dilakukan dengan memiliki pengetahuan sebaik-baiknya atau dengan melakukan suatu perbuatan sebaik mungkin (Ismail, 2011).

Islam memberikan ajaran bahwa aktivitas yang melahirkan suatu produktifitas tertentu akan terasa bermakna dan terkontrol bila didasarkan Iman karena Allah SWT. Dengan mendasarkan semua aktifitasnya kepada Yang Maha Kuasa aktitifitas yang dilakukan akan melahirkan semangat kerja yang tak lekang karena panas dan tidak rapuh karena guyuran hujan. Semangat dilakukan dalam rangka mendapatkan ridlo Allah SWT (ibtighoan li mardlotillah).

Hasil pengujian jalur langsung ini (tanpa melibatkan variable mediasi) diperoleh nilai beta 0.877 dengan nilai $\mathrm{p}$ value sebesar 0.000 ; maka dapat disimpulkan bahwa personal value sebagai variabel mediasi sebagian (partial mediation) pengaruh budaya organisasi terhadap perilaku ihsan. Hasil penelitian menegaskan bahwa budaya organisasi berkaitan dengan bagaimana karyawan mempersepsikan karakteristik dari suatu budaya organisasi, bukan dengan apakah para karyawan menyukai budaya atau tidak, sehingga apa yang dipersepsikan karyawan dan cara persepsi itu menciptakan suatu pola keyakinan, nilai, dan ekspektasi. Lebih lanjut dikatakan bahwa budaya organisasi mampu membentuk sikap anggota yang nantinya akan berdampak pada perilaku anggota organisasi. Budaya organisasi melibatkan ekspektasi, nilai, dan sikap bersama, hal tersebut memberikan pengaruh pada individu, kelompok, dan proses organisasi (Ivancevich et.al., 2006).

Manifestasi perilaku ihsan dapat dilakukan dengan memiliki pengetahuan sebaik-baiknya atau dengan melakukan suatu perbuatan sebaik mungkin (Ismail, 2011). Jadi ihsan mengajarkan kepada kita tiga hal, yaitu melakukan sesuatu seoptimal mungkin, mengimprovisasi pengetahuan dan kemampuan yang berkaitan dengan tugas sehingga dapat bekerja seoptimal mungkin, menjauhkan diri dari bekerja asal-asalan yang bertentangan dengan ajaran agama islam

\section{KESIMPULAN DAN SARAN}

Budaya Organisasi mampu menciptakan personal value, yang berfungsi sebagai suatu pola dari asumsi dasar yang diciptakan, ditemukan, atau dikembangkan oleh kelompok tertentu saat belajar menghadapi masalah adaptasi eksternal dan integrasi internal, sehingga perlu untuk diajarkan kepada anggota baru sebagai cara yang benar untuk berpersepsi, berpikir dan berperasaan sehubungan dengan masalah yang dihadapinya. 
Personal value akan mempengaruhi perilaku sehingga harus dibangkitkan dari dalam diri seseorang atau dari lingkungan.

Perilaku ihsan merupakan optimalisasi kerja dan berbuat, bekerja, dan melaksanakan tugas sesuai dengan kinerja yang serba baik dan berkualitas tinggi, sehingga perilaku ini harus dikembangkan dan dibudidayakan.

Personal Value telah meningkatkan keragaman perilaku ihsan sehingga dapat dikatakan bahwa personal value memediasi pengaruh budaya organisasi terhadap perilaku ihsan.

Budaya Islami merupakan bagian penting yang membedakan UIN Malang dengan lembaga Perguruan Tinggi non Islam lain yang tidak bersandarkan nilai Islami, oleh karena itu diperlukan perangkat dan alat untuk membumikan nilai-nilai Islami yang menopang budaya kerja yang diharapkan guna tercapainya visi dan misi UIN Malang.

Memasukkan ukuran organisasi sebagai variabel kontrol, sehingga pemetaan hasil penelitian menjadi semakin jelas dan terarah.

Menambahkan variabel kepemimpinan ke dalam model penelitian, karena sebaik apapun budaya organisasi tanpa didukung model kepemimpinan yang tepat, hasilnya tidak bisa maksimal.

\section{DAFTAR PUSTAKA}

Al-Quran al - Karim. 2010. Kementerian Agama RI.

Buchari, Alma. 2009. Manajamen Pemasaran Dan Pemasaran Jasa. Bandung. CV Alvabeta.

Ellinger, Alexander E., Carolyn (Casey) Findley Musgrove, Andra D. Ellinger, Bachrach, Yu-Lin Wang. 2012. Influences of organizational investment in social capital on servise employee commitment and performance. Journal of Business research. 1-10.

Handayanto. (2014). Pengaruh Budaya Organisasi terhadap kepemimpinan, personal value, dan perilaku ihsan. PPSUB
Gibson, James, J.M Ivancevic and J.H Donnelly 1996. Organisasi, Perilaku, Struktur, Proses. Edisi kedelapan Jilid I. Terjemahan Nunuk Adiarni. Binarupa Aksara . Jakarta

Hofstede, Geert. 1990. Attitude, value, and organizational culture- disentangling the concept. Organization Studies. 477-492.

Ibrahim, S. (2006). Keadilan Sosial Dalam Perspektif Islam. Quo Vadis Pendidikan Islam. UIN. Malang Press

Ismail, Ahmad Ilyas. (2011). Islam The Straigh Way : Ya Allah Berilah Aku Kesuksesan. Bogor. Bela Book Media Group.

Lages, Luis Filipe and Joana Cosme Fernandes. 2005. The Serqual scale : a multi item instrumrnt for measuring services personal values. Journal of Business Research Volume 58. 156- 157.

Ogbonna, Emmanuel and Lloyd C Harris. 2000. Leadership style, organizational culture and performance : empirical evidence from UK companies. The International Journal Of Human Resource Management. 11 (4) : p 766-788.

Robbins, S. 2006. Perilaku Organisasi: Konsep, Kontroversi Dan Aplikasi. Edisi Kedua. Terjemahan Pudjaatmaka. Prenhallindo. Jakarta.

Sekaran, Uma. 2003. Research Methods For Business A Skill- Building Approach. John Wiley and Sons. USA.

Siswanto dan Sucipto Agus. 2008. Teori dan Perilaku Organisasi. UIN Malang Press. Malang

Solimun. 2012. Pemodelan Persamaan Struktural Generalized Structured Component Analysis. GSCA. Disampaikan pada DIKLAT Aplikasi Statistika Multivariat: GSCA. Program Studi Statistika. Universitas Brawijaya. Malang.

Wu, Tsung Yu, Changya Hu dan Ding Yu Jiang. 2012. Is subordinates loyalty a predondition of supervisor,s benevolent leadership ? The moderating effect of supervisor altruistic personality and perceived organizational support. Asian journal of social Psychology. 145-155. 